\title{
The Politics of United States Foreign \\ Policy under Barack Obama
}

\author{
La Politica Exterior de los Estados Unidos
}

en la administración de Barack Obama

\section{ROBERT C. LIEBERMAN}

Columbia University

\begin{abstract}
I devote most of this essay to the task of placing Obama's presidency in long-run historical context. Obama's election comes at a critical moment in American political history, at the end of one political era and on the edge of another. What matters in such circumstances, I will argue, is more what Obama is against than what he is for. We also need to take careful account of the political constraints on what he is and is not able to do. As the great American baseball player Yogi Berra is supposed to have said, "It's tough to make predictions, especially about the future."
\end{abstract}

Key words: OBama's presidency, Foreign policy.

\section{RESUMEN}

La tarea a la que me dedico en buena parte de este ensayo es la de poner la presidencia de Barack Obama en un contexto histórico de largo plazo. Su elección a la presidencia de los Estados Unidos sucede en un momento crítico para la historia política de los Estados Unidos: marca a la vez el fin y el inicio de una era política. Sostendré que, en estas circunstancias, es más importante aquello contra lo que se opone Obama que aquello que defiende. También es necesario tomar en cuenta los constreñimientos políticos que determinará lo que podrá o no podrá hacer. En esta materia, así como, supuestamente, dijo Yogi Becerra, un gran jugador de baseball estadounidense, "es muy difícil hacer predicciones, especialmente acerca del futuro".

Palabras Clave: Presidencia de Obama, política exterior. 


\section{INTRODUCTION}

Once in a while, someone becomes president of the United States after a career that includes extensive experience in foreign policy. Dwight Eisenhower, for example, had spent his life in the military and commanded the allied forces in Europe during World War II and NATO after the war. Richard Nixon had a long record in office, as a member of Congress and vice president, during the cold war. George H. W. Bush (the father, not the son) had been ambassador to China and director of central intelligence as well as vice president before becoming president. And occasionally a president arrives in office without much experience but with a very clear-headed approach to foreign affairs laid out in his campaign. Such was the case, for example, with Ronald Reagan, who had been an actor and union leader in Hollywood before he became a television spokesman for conservative causes and governor of California. Despite his limited background, he arrived in the White House with a very clear, some would say simple-minded, view of the place the United States should occupy in world affairs and of its great rival at the time, the Soviet Union (which he called, with theological certainty, "an evil empire") (Reagan 1984, 1: 363).

But just as frequently, presidents come to office with little or no experience in foreign policy. Bill Clinton and George W. Bush (the son) had been state governors before becoming president - not exactly a source of foreign policy experience. In fact, during his presidential campaigns, Bush's opponents routinely (if not always accurately) made fun of him for barely even having traveled outside the United States before becoming president (Smith 2003, Dobbs 2007).

It is fair to say that Barack Obama falls into this latter category of inexperienced presidents in terms of foreign affairs. Before he was elected the United States Senate in 2004, he had worked as a community organizer in Chicago, as a civil rights lawyer, and as a law professor at the University of Chicago. It is true that he lived in Indonesia for a time in his childhood and traveled extensively in Africa as a young adult. Both of these experiences are chronicled in his extraordinary memoir, Dreams from My Father, but they do not really count as credentials in foreign policy (Obama 2004). As a United States senator he did serve on the Committee on Foreign Relations and served as chairman of the Subcommittee on European Affairs, but while he was chair he spent most of his time running for president so he was not very active in this role.

So how do we assess the foreign policy prospects of a president whose background give us so little to go on? There are several conventional ways we might do this. One is to look at what Obama said as a candidate about foreign policy. This proves to be a very unreliable guide, even in Obama's case. When Obama began his campaign for president more than two years ago, foreign policy was actually his strongest political case for the Democratic nomination, specifically his early opposition to the war in Iraq. The other leading contenders for the nomination - especially Hillary Rodham Clinton, John Edwards, and Joe Biden - had supported the Senate resolution authorizing the war. Obama was not yet a senator then and so was not forced to vote, but he had been an early and vocal critic of the war, and this was his distinguishing feature as a candidate. But as the campaign wore on, foreign policy moved to the periphery of Obama's rhetoric. Once he had vanquished his Democratic rivals and was facing John McCain in the general election, foreign policy was 
no longer an area of comparative political advantage for him. Moreover, by the time of the general election, the situation in Iraq had stabilized somewhat (although the war was still deeply unpopular) and the economy was in freefall, which gave Obama something more compelling to talk about. In his campaign, Obama did give us hints about specific foreign positions on a variety of foreign affairs issues, but he hardly can be said to have laid out a coherent foreign policy doctrine.

Some observers have tried to discern an "Obama Doctrine" in the first months of the Obama administration. E. J. Dionne (2009) of the Washington Post wrote in April that, "The Obama Doctrine is a form of realism unafraid to deploy American power but mindful that its use must be tempered by practical limits and a dose of self-awareness". Others have pointed similarly to elements of an emerging "Obama Doctrine": legalism, multilateralism, a measure of humility in the projection of American power around the world. On the other hand, David Sanger (2009) of the New York Times described Obama's foreign-policy approach as more of an "anti-Bush doctrine" than an affirmative grand strategy on its own. The Times rightly points out that it is risky to try to identify a clear policy framework after just a few months of a new presidency. After all, they point out, "anyone who tried to discern one 77 days into the Bush administration in 2001, months before the terrorist attacks of Sept. 11, would have gotten it completely wrong". After all, Bush had campaigned in 2000 against exactly the kind of "nation-building" that his administration tried to achieve in Iraq. I think the Times's description of an "anti-Bush doctrine" gets us closer to the truth, although as I will explain, I arrive at this conclusion for different reasons.

A second way common way that observers try to view a president's foreign policy is by looking at who he chooses as his chief foreign-policy advisors. Journalists love to do this. Newspapers and web sites are full of lists of advisors, appointees, and assorted other affiliates, as if knowing who these people are can tell us how the president thinks. But this also proves to be a fool's errand. If we know anything about Obama as president thus far, it is that he is supremely confident in his own intelligence and ability to grasp complex policy issues, and will not be easily swayed by even the most single-minded and strong-headed group of advisors or experts. Neither of the top two foreign policy officials in Obama's administration -Secretary of State Hillary Clinton nor National Security Advisor James Jones- is clearly identified with a coherent doctrine of international affairs, so it is hard to discern a pattern here.

Instead, I want to propose and defend a different approach to understanding the prospects for Obama's foreign policy. My approach depends less on observing the details of foreign policy itself and more on understanding the political background of the Obama administration. What political constraints and opportunities confront Barack Obama in the early phase his administration? What are the sources of those constraints and how can we make sense of them? What might they portend for the foreign policy choices of the next four (or eight) years?

In order to offer a provisional answer to these questions, I devote most of this essay to the task of placing Obama's presidency in long-run historical context. Obama's election comes at a critical moment in American political history, at the end of one political era and on the 
edge of another. What matters in such circumstances, I will argue, is more what Obama is against than what he is for. We also need to take careful account of the political constraints on what he is and is not able to do. As the great American baseball player Yogi Berra is supposed to have said, "It's tough to make predictions, especially about the future". I will heed Berra's very sound advice and try not to make predictions about what Obama may or may not do in foreign affairs. But I will avoid making predictions not because I worry that I might be wrong but because, as I will argue, given Obama's historical circumstances it is virtually impossible to make intelligent predictions about what his administration might amount to. What matters most is Obama's stance as the anti-Bush, but as I will show, working out just what this means for policy is not an easy matter.

\section{THE OBAMA PRESIDENCY IN HISTORICAL CONTEXT}

The American presidential election of 2008 was, as many have noted, a historic event. This was true for a number of different reasons, some obvious, others more hidden. Most obvious, perhaps, was the election of an African-American as president of the United States. After centuries of enslavement, repression, segregation, and denial of rights -and only a generation after the civil rights revolution of the 1960s- this is an important milestone. If you had suggested to most sophisticated political observers just a few years ago that a black man would become president in 2008, you would have been dismissed as either a hopeless idealist or a crackpot.

Second, Obama's election seems to have resonated around the in a way that few American political events have done in a long time. Obama, in particular, seems to have captured the world's imagination more than most American political figures. Even as a candidate for president, Obama drew an estimated 200,000 people to an outdoor speech he gave in Berlin in July 2008. As Kishore Mahbubani (2008), one of Singapore's leading diplomats and foreign affairs experts, wrote in January 2008, "in one fell swoop, an Obama victory would eliminate at least half of the massive anti-Americanism now felt around the world. Eight hundred million Africans would get a tremendous boost to their self-esteem and cultural pride... The 1.2 billion Muslims in the world," Mahbubani went on, "would take great interest in his middle name: Hussein. Indeed, the election of ' $\mathrm{H}^{\prime}$ would immediately undo much of the damage ' $W$ ' has wrought". Mahbubani's pre-election optimism may have been somewhat overstated; after all, now that Obama is president, the United States remains the world's leading power, and its engagements around the world are no less popular than they were before he took office. But if the electric reaction to Obama's election and the public reception he has received on his travels abroad as president are any indication, he still has international star quality, and he seems to project a somewhat different image of American power in the international sphere.

But I want to suggest a third, and more subtle, way in which Obama's election represents a historic turn for the United States and its relations with the rest of the world. I think it is safe to say that Obama's election marks the end of the Ronald Reagan era in American political history. And I want to argue that it is this moment of potential regime transformation in 
American politics that will, more than anything else, define the possibilities for foreign policy in the Obama administration.

This view relies on long-term historical view of presidents and their roles in history, and so I begin by placing Obama and his election in historical context. I borrow here from the perspective of the American political science Stephen Skowronek (1993), who takes a cyclical view of the presidency in American history. Skowronek identifies long periods in American history when stable groupings of voters, parties, ideological commitments, and policy ideas come together and define the national agenda for a period of years, and typically for decades. In each of these periods, or regimes, a common, dominant understanding of public policy emerges, backed by a core coalition of loyal voters. In each period, presidents are identified by their relationship to the dominant regime-either affiliated with the regime or in opposition to it- and their policy strategies and opportunities for leadership are largely defined by this relationship. Presidents affiliated with the dominant regime are generally expected to stick to its core policy commitments and extend them; oppositional presidents must push against the dominant trend, not always an easy task. These regimes have a sort of natural life cycle. They are born at moments of great disruption or uncertainty -such as the American Civil War of the 1860s or the Great Depression of the 1930s- when old patterns of policy and ideology become dysfunctional and discredited.

The new coalitions formed at these moments of dramatic transformation reign triumphant for a time, often a matter of decades, and a generation of politicians - presidents includeddefine themselves in reaction to the prevailing understanding of politics and policy, either for it or against it. For a time, the regime is dominant; its adherents wield power and influence while its opponents often have to moderate their opposition. But eventually the world changes. New challenges emerge and new policy problems arise that the old regime is ill equipped to address. The regime's internal contradictions are exposed and exploited by its opponents, it begins to lose legitimacy, and it becomes the discredited old regime that is defeated by something -and someone- new, and the cycle begins again. But these patterns do not happen by themselves; they happen because they define the challenges facing each president that serves under them.

\section{THE PRESIDENCY AND THE NEW DEAL ORDER}

Let me illustrate this approach more concretely and in some detail by offering a historical tour of the presidency since the 1920s, culminating in the presidency of Barack Obama, which I think potentially marks the beginning of a new regime in American political history. After we have followed the history of the American presidency in this way, we will, I think, be in a better position to assess the direction that Obama's policies might take.

I begin with the broad period in the middle of the twentieth century, beginning with the Great Depression. When the Depression began in 1929, American politics had been dominated by the Republican Party for more than thirty years. The period of Republican dominance, especially in the 1920s, had been one of growing isolationism, especially with respect to Europe, as the United States retreated from its reluctant engagement in World 
War I. Economically, it was a period of limited government, low taxation, and minimal governmental regulation of the economy and society. The banker and philanthropist Andrew Mellon served three Republican presidents in the 1920s as secretary of the treasury, and his main policy aim was to reduce the public debt that the United States government had incurred in fighting World War I (the debt was approximately $\$ 24$ billion when Mellon became secretary in 1921, a figure that alarmed economists and businessmen at the time, but seems minuscule compared to a public debt of more than $\$ 11$ trillion today) (Wallis 2006). Herbert Hoover, who was elected president in 1928, was committed to continuing these orthodox Republican policies, and was reluctant to deviate from them even when the Depression began in the first year of his presidency. His administration's approach to the economic distress of the Depression relied heavily on voluntary measures to stimulate the economy and bail out failing banks, railroads, and farms in the early 1930s (Burner 1979). Toward the end of his term, he grudgingly accepted some federal intervention in the financial system, but refused to sanction any direct federal relief for unemployment, which reached nearly 23\% in 1932 (Carter 2006).

In the international realm, Hoover maintained the isolationism of the 1920s. He also supported and signed the notorious protectionist Smoot-Hawley Tariff Act of 1930, which raised tariffs on many imported goods, leading to retaliation by other countries and contributing further to the decline of international trade. And he began to relax somewhat the American policy of aggressive engagement in Latin America (DeConde 1951). (Hoover traveled to Central and South America shortly after he was elected for a goodwill tour of the region. His visit was met generally with enthusiasm, although he encountered a fair number of protests against "Yankee imperialism" as well as a failed assassination plot against him in Argentina). Hoover took steps to institute a one-year moratorium on the payment of German reparations to the victorious World War I powers, but that did little to ease the international economic crisis. By the end of Hoover's presidential term, the Depression, both in the United States and around the world, had arrived at its lowest point. The international economic system seemed to be on the verge of collapse, and to many observers the very future of liberal democracy - under assault in Europe from Bolshevism and fascism- seemed uncertain.

By the time of the 1932 presidential election, the economy had failed to recover, the international economic system seemed in danger of collapse, and to many observers the future of liberal democracy -under assault from the twin challenges of Bolshevism and fascism- seemed very much in doubt. Little was clear except that Hooverism -the combination of limited governmental intervention and protectionism in response to the Depression- was widely deemed a failure and the generation-old Republic regime that Hoover represented was thoroughly discredited. Hoover was defeated in his bid for reelection by Franklin Roosevelt, who won more than 57\% of the vote, the largest presidential landslide in American history until that point.

So Franklin Roosevelt became president at a time of profound uncertainty and tremendous crisis when the old, conventional ways of doing public policy had been completely discredited. In place of the Republican orthodoxy of the preceding generation, Roosevelt built something new -the collection of policies and the political coalition that we now know 
as the New Deal- that proved to be enduring and resilient, dominating American politics for nearly fifty years. The New Deal brought together groups of voters in the Democratic Party who were united in their rejection of the Republican approach to policymaking -voters in the South, the poorest and most underdeveloped region of the country; the industrial working class of the cities; and rural voters in the West-but who had little else in common politically. During a twelve-year presidency, Roosevelt massively reformed American government and public policy, developing a broad liberal consensus on the role of government in regulating the economy, providing social protection, and protecting rights. And Roosevelt won an even bigger landslide when he was reelected in 1936 than he had in 1932 (Leuchtenburg 1963; Badger 1989).

Roosevelt also rejected the Republican foreign policy approach of the previous generation. During the late 1930s, he deftly maneuvered the country away from isolationism and toward a stance of more assertive internationalism, rejecting American neutrality in favor of assistance to France and Britain in the fight against Nazism and eventually bringing the country into World War II. His partnership with Winston Churchill and cautious engagement with Stalin toward the end of the war set the pattern for continued American engagement in the postwar world. Roosevelt was also an advocate of free trade; along with his secretary of state, Cordell Hull, he pursued reciprocal trade agreements with a number of countries around the world, including several South American countries. And among the chief foreign policy directions of Roosevelt's first term was the Good Neighbor Policy toward Latin America, under which the United States shifted the balance away from military intervention and toward economic and cultural means of exerting influence in the region (Dallek 1979, 17-18, 38-39; LaFeber 1983, 79-83). In all, the Roosevelt years established a new dominant pattern in American politics, characterized by more active and vigorous government both at home and abroad, backed by a new liberal ideology and a strong supportive coalition.

Once the New Deal had been established as the dominant paradigm in American political life, the careers of presidents who came after Roosevelt were defined by their relationship to Roosevelt's legacy and the New Deal (Leuchtenburg 1983; Fraser and Gerstle 1989). Harry Truman, the vice president who succeeded to the presidency on Roosevelt's death in 1945, was closely affiliated with the New Deal, and that affiliation entirely defined Truman's presidency. His own policy program, which he called the "Fair Deal" in echo of Roosevelt's New Deal, was almost entirely structured around extending and perfecting the New Deal program. In some respects he was successful: in foreign policy he maintained the Roosevelt administration's posture of energetic engagement in the world, particularly in confronting in the reconstruction of Europe through the Marshall Plan and the policy of containing the Soviet Union. Truman embraced the new stature of the United States as a world power, and fought back forces in the United States who wanted to retreat back into isolationism as the country had after World War I. On the domestic front, Truman promoted, in a very limited way, the use of government power to protect rights, particularly civil rights for American blacks. But this policy stance threatened to alienate a core part of the Democratic coalition, Southern white voters who wanted to protect the severe racial segregation and repression of their region. So as early as the 1940s, the New Deal regime's internal contradictions were beginning to show. In other respects, Truman 
was much less successful: his push for the expansion of the New Deal welfare state, particularly for national health insurance, did not succeed, and some of the labor rights that had been won under Roosevelt were rolled back. For all is accomplishments and ambition, Truman could never really be a truly innovative president on his own because he was essentially the carrier of the new New Deal orthodoxy and he was there to carry on the Roosevelt legacy.

Truman's successor was Dwight Eisenhower, a Republican and the first opposition president of the New Deal era. When Eisenhower was elected, conservative Republican opponents of the New Deal were elated because they thought that his presidency would spell the end of the expansive government of the New Deal. But Eisenhower couldn't really oppose the New Deal's policies, except around the edges, because they remained basically popular and still commanded the support of most Americans (and the Democrats, Roosevelt's party, retained control of Congress for most of Eisenhower's presidency, limiting his ability to make policy).

After John Kennedy's shortened presidency, Lyndon Johnson built his program around a further embrace and extension of New Deal liberal commitments. Johnson, whose political career had begun as the director of a New Deal program in Texas in the 1930s, saw his presidential mission as completing and perfecting the New Deal. He presided over a "war on poverty," the expansion of social welfare programs (including the creation of national health insurance for the elderly and the poor), and federal protection of civil and voting rights for blacks. Johnson's championing of African-American rights, while in one sense a logical extension of the New Deal's program, also created a rift between two key constituencies of the New Deal coalition: Southern whites, who opposed civil rights, and blacks, who supported them. Johnson's escalation of American military commitments in Vietnam into full-scale war had a similar effect. On the one hand, the Vietnam War was entirely consistent with cold-war American foreign policy. On the other hand, it, too, caused a rift within the Democratic Party. Democrats disagreed among themselves about the aggressive internationalism of New Deal liberalism.

Richard Nixon, one of the leading opposition figures of the New Deal era, succeeded Johnson as president. Nixon had been Eisenhower's vice president and in many respects his presidency mirrored Eisenhower's. Although he was opposed to the dominant New Deal regime, many of his policy accomplishments accommodated New Deal aims, especially in domestic policy, where he presided over a broad expansion of government regulation in areas such as the environment, health, and labor (Wicker 1991; Hoff 1994). At the same time, Nixon was able to find and exploit growing divisions within the New Deal coalition on issue after issue -including race relations, social welfare, and foreign policy- to which old New Deal solutions no longer seemed to apply and where the broad liberal consensus had become shaky. Nixon himself came to grief, forced to resign as the result of a scandal, but his presidency highlighted the increasing fragility of the New Deal order. By the time the Democrat Jimmy Carter came along in 1976, the New Deal had been more or less discredited and the coalition was in pieces (Schulman 2001). Carter himself, although a Democrat, began to pursue policies that looked much more like the opposition such as economic deregulation and increased defense spending. When Carter ran for reelection in 
1980, the Soviet Union had occupied Afghanistan, radical Iranian students were holding hostages in the American embassy in Tehran, and the economy was in dire straits with inflation, unemployment, and interest rates all in (or approaching) double digits. The New Deal was a spent force and the apparent failures of the Carter years paved the way for the Reagan Revolution, which began in 1980s and started the cycle all over again.

\section{THE REAGAN ERA}

We can tell much the same story about the Reagan era. Now it was Reagan who was the disruptive force who came to power at a moment of crisis and uncertainty. Domestically, thirty years of postwar prosperity seemed to be coming to an end, and the New Deal approach to macroeconomic management was no longer adequate to address the looming economic crisis (which would blossom into full-blown recession in the early years of Reagan's presidency - the deepest American recession between the Great Depression and the present one). For many American voters, including many Democrats, the New Deal itself was the culprit for the country's economic and social distress: high taxes, excessive regulation, expansive social programs, and civil rights. The monetarist theories of Milton Friedman, Robert Lucas, and others provided intellectual backing for the rejection of Keynesianism and the scaling back of government intervention in the economy. Internationally, defeat in Vietnam had divided the Democratic Party between hawks and doves and led to the perception that American power in the world was declining and that the country was at risk of falling behind the Soviet Union in terms of military capability and international influence. The oil shocks of the 1970s gave Americans a new sense of vulnerability to world events and international forces that was unsettling to many and further fueled discontent with the old New Deal orthodoxy.

The Reagan Revolution was the answer to the now-discredited New Deal. Reagan came to office as an anti-New Dealer (although ironically, Reagan had been a supporter of Roosevelt in the 1930s). He pledged lower taxes, a government of more limited size and scope, a rebuilt American military, and renewed attention to national security and the cold war. Perhaps the key moment of the 1980 presidential campaign, which perfectly encapsulates Reagan's stance as an opponent of a defunct regime, came in the televised debate between Carter and Reagan in October 1980. At one point in the debate, Carter launched into a criticism of Reagan's record with regard to Social Security (retirement pensions) and Medicare (health insurance for the elderly), two core New Deal-era social programs. After Carter finished his comment, Reagan looked across the stage at the president and said genially, with his familiar head-bob, "There you go again". With that one short, quiet phrase, Reagan portrayed Carter as a backward-looking adherent of a failed approach to government, without new ideas or fresh thoughts about public problems. In the closing minutes of the debate, Reagan, always at his best in front of a camera, stared directly at the viewers and asked, "Are you better off than you were four years ago?" He knew full well that for many, if not most, of the people watching, the answer would be "no," and by framing the question as a referendum not just on Carter but also on the whole New Deal experiment, he presented himself as something altogether new. 
Reagan's presidency largely delivered on his promised rejection of the old regime. Taxes on individuals and businesses were lowered and the tax code was reformed and simplified. Business was deregulated and social welfare programs rolled back. Military spending rose, new weapons systems were built, and a missile defense research program was started. American foreign policy took on a more confrontational stance toward the Soviet Union, through both the military buildup and the projection of American power around the world after a hesitant and halting decade - in Europe, the Middle East, the Caribbean, and of course in Latin America, where the United States supported anticommunist insurgencies and regimes (through means both legal and illegal).

The presidents who followed Reagan were measured against him and his agenda. The first George Bush, Reagan's loyal vice president, found himself, much like Truman, constrained by his prescribed role as the keeper of the Reagan tradition. In his own foreign adventure, the First Gulf War of 1990-91, Bush found success in the Reagan mold. But in domestic affairs, his affiliation with the Reagan regime did not serve him so well, and his presidency foundered on one of Reagan's signature issues, taxes. Bush broke his notorious "Read my lips, no new taxes" pledge in negotiating a budget deal with Congress in 1990, and the fallout from that decision haunted the rest of his presidency. As a keeper of the Reagan orthodoxy, Bush did not quite measure up in the end. He found he had very little political leeway to deviate from the Reagan program even when, in his judgment, the occasion demanded it.

Bill Clinton, who defeated Bush in 1992, was the first oppositional president of the Reagan era. Clinton's place in the Reagan regime paralleled Nixon's position with regard to the New Deal: the ambitious challenger president serving under a still robust and popular regime, to which he was basically opposed. Clinton's genius, like Nixon's, lay in his ability, as an opposition figure, to appropriate elements of the regime's agenda and claim them as his own. After Clinton's ambitious, New Deal-like plan to enact national health insurance failed in 1994, Clinton's Democrats lost control of Congress and he was forced to scale back his policy ambitions and align them more closely with the prevailing regime, and in 1996 he announced, with all apparent sincerity, that "the era of big government is over". It was Clinton who signed a welfare reform package in 1996 that rolled back one of the core social enactments of the New Deal. It was Clinton who oversaw the ratification of the North American Free Trade Agreement, over the strenuous objection of parts of his core Democratic constituency, especially labor unions. And it was Clinton who, in the late 1990s, orchestrated American-led NATO military intervention in Serbia and Kosovo. Caught like Nixon between the imperative of opposition and the fundamentally robust prevailing regime, Clinton had to triangulate carefully in pursuit of policy. And like Nixon, Clinton got under the skin of his opponents more than any other political figure of his era. And Clinton almost shared Nixon's fate; impeached for his own scandalous behavior, he was acquitted by the Senate in 1999 and remained president. But his experience of the presidency remains a cautionary tale for oppositional presidents.

All of which brings us to George W. Bush (the son) - remember him? Bush won the election of 2000 (just barely) on a platform of more or less orthodox Reaganism: lower taxes, a smaller welfare state including partly privatized Social Security, an aggressively 
pro-business approach to government regulation and economic policy, and an equally aggressive unilateralism in world affairs (as in, for example, the rejection of the Kyoto Protocol on climate change). After the terrorist attacks of September 11, 2001, the Bush agenda turned largely toward foreign affairs and national security, beginning with military action first in Afghanistan and then the invasion and occupation of Iraq. After a quick military victory, however, Bush's Iraq adventure did not, shall we say, go terribly well, and the country began to lose confidence in Bush's strategic vision and in his approach to foreign policy. Like Vietnam for Lyndon Johnson, Bush's war in Iraq was entirely consistent with the prevailing governing philosophy with which his presidency was aligned: bold confidence in the projection of American military power around the world in the service of more or less ideological aims. But like Vietnam, it began to expose the limits and contradictions of that philosophy and of the entire edifice of the Reagan regime, particularly an approach to foreign affairs that was conceived to wage and win a cold war against a rival power, not to confront a terrorism threat that emerged from multiple states and, more significantly, from murkier and often hidden non-state actors such as al-Qaeda. By the time of the 2008 election, Bush's domestic policies, too, seemed inadequate to cope with the country's deepest recession since the 1980s and its most serious financial crisis since the 1930s, which seemed to result largely from the lack of regulation imposed on big investment banks, insurance companies, and other financial actors during the Bush years. Like Carter in 1980, Bush came to seem helpless and backward-looking, unable to summon the political or intellectual resources to meet the country's current challenges.

The unfortunate heir to the Reagan-Bush mantle was John McCain, the Republican nominee for president in 2008. Perhaps the best evidence of the political bankruptcy of Reaganism by 2008 was the state of disarray of the Republican Party during last year's presidential campaign. One of Reagan's great political accomplishments was that he deftly and skillfully knitted together three conservative constituencies who, like the groups that made up the New Deal coalition, were not necessarily natural allies. The first was Christian conservatives, mostly evangelical Protestants from the south and west of the country. These voters are primarily concerned with social and moral issues, from abortion to prayer in public schools and religion in public life more generally, from the teaching of evolution in science classes to stem cell research and same-sex marriage. The second was traditional economic conservatives, mostly business-oriented and affluent voters who emphasize low taxes, small government, laissez-faire economic policies, and minimal regulation. These voters do not necessarily share the moral and religious views of the Christian right. And often in American history, these economic conservative voters have tended toward isolationism in foreign affairs, which has divided them from the third pillar of the Reagan coalition, the national security conservatives, including the so-called "neoconservatives". This group is primarily interested in a strong, some would say belligerent, American foreign policy. Many people in this category were former Democrats who were alarmed by the country's defeat in Vietnam and what they saw as the Democratic Party's subsequent loss of nerve and its subsequent anti-militarist turn. Many leading neoconservatives, of course, played prominent roles in the Bush administration's foreign policy decision-making. 
What these groups had in common in the 1970s and 1980s was a shared disdain for the New Deal order, and Reagan was able to successfully combine them into a powerful ruling coalition that dominated American politics for nearly thirty years. But in the 2008 presidential campaign, the internal stresses on this coalition began to show. The contest for the Republican presidential nomination was a not-too-friendly contest among candidates representing these three groups, none of whom quite trusted one another. Mike Huckabee (a Baptist minister and the former governor of Arkansas, now a television talk-show host) was the candidate of the Christian right. Mitt Romney (the former governor of Massachusetts and a former management consultant and private equity investor) was the candidate of the economic conservatives. And John McCain (a former Navy pilot and prisoner of war in Vietnam) was the national security candidate. The other groups never quite trusted him and his nomination brought only an uneasy peace to this increasingly unstable coalition, but as the McCain campaign foundered, we found that we were watching the Reagan coalition fall apart while the world watched.

\section{OBAMA AND THE POLITICS OF TRANSFORMATION}

The beneficiary of this collapse of Reaganism, of course, was Barack Obama, and I want to suggest that Obama's election marks another potential moment of regime transformation in American history. Obama, much like Roosevelt and Reagan, was primarily a candidate of opposition to the previous regime. The parallels between Obama and Roosevelt are striking. Both came into office at moments of global economic crisis and deep domestic distress. Both replaced presidents, and regimes, that had been fundamentally discredited. And, strikingly, both, in their public rhetoric, carefully avoided making clear and definitive ideological or programmatic commitments. Recall, for a moment, Obama's remarkable presidential campaign. His principal campaign slogan was, "Change We Can Believe In," which means - what, exactly? Nothing, really. Or whatever a listener wants it to mean. What it does convey, quite concisely and evocatively, is fundamental dissatisfaction with what has come before. What it does not convey is exactly what the new president is committed to in policy terms. This stance is consistent with what we know about Obama from his earlier public life. Obama first became a national figure in the United States when he made a well-received speech at the 2004 Democratic National Convention, in which he distanced himself from clear ideological statements. In the most quoted passage from that speech, Obama said, "Now even as we speak, there are those who are preparing to divide us -the spin masters, the negative ad peddlers who embrace the politics of 'anything goes.' Well, I say to them tonight, there is not a liberal America and a conservative America- there is the United States of America" (New York Times, July 27, 2004). In his campaign, Obama did take policy positions, but they tended toward vagueness, on the order of "end the war in Iraq," or "increase the American presence in Afghanistan," or "engage more fully with Iran," rather than specifics.

This tendency toward vagueness of policy commitments and the avoidance of ideology is a characteristic that Obama shares with other transformative presidents. The presidents who came to power at moments of great crisis did not generally enter the presidency 
with a clear path mapped out toward the great achievements we associate with them in hindsight. The clearest example of this phenomenon is Abraham Lincoln, who was elected president in 1860 in the midst of the gravest political crisis in American history. By the time Lincoln took office in March 1861, seven southern states had seceded from the United States to form the Confederate States of American and were prepared to take arms against the United States to defend their right to maintain slavery. (They did take arms against the union, and the country fought a bloody civil war between 1861 and 1865.) Although Lincoln's personal aversion to slavery had long been clear, his policy approach toward southern slavery was anything but clear and he deliberately and carefully avoided saying anything that would clarify it until he absolutely had to act. There is simply no way to predict from his presidential campaign or from his actions early in his administration that he would, in 1863, issue the Emancipation Proclamation ending slavery in the United States, which is now seen as the great achievement of his presidency. And when he did issue the proclamation, it read not like a great statement of ideology or principle but like a military order written by a skilled lawyer - which is exactly what it was. As the great American historian Richard Hofstadter $(1948,131)$ wrote of the proclamation, it "had all the moral grandeur of a bill of lading". And as Lincoln himself was fond of declaring, "my policy is to have no policy" (Donald 1995, 332). Lincoln was not an ideologue; he was a pragmatist down to his bones, and in this way he preserved maximum freedom of maneuver for himself at all times.

Franklin Roosevelt, too, was fundamentally a pragmatist. In hindsight, we associate the New Deal with a highly coherent and vigorous form of programmatic liberalism. Over the course of the his presidency, his administration reformed and regulated the financial system, mounted a massive program of work relief for the unemployed, reorganized the American agricultural economy, built extensive public works that enhanced the national infrastructure and put millions to work, established a system of public retirement pensions and unemployment insurance, and protected labor rights, and laid out an ambitious postwar agenda (still mostly unfulfilled) of expansive social rights. This is the essence of the program we now call the New Deal. But the phrase "new deal" comes originally from Roosevelt's acceptance speech to the Democratic National Convention in Chicago in 1932, a speech that mentions jobs and economic security but is mainly concerned with free trade and the need to restrain government spending (Roosevelt 1938, 64759). Many historians have pointed out that what became the New Deal emerged only after many false starts, dead ends, and seemingly contradictory policies (Hawley 1966). As with Lincoln, there is simply no way to predict from Roosevelt's early presidential pronouncements -or even from the enactments of the famous first hundred days of his presidency- what kind of a president he would become or what accomplishments we would remember him for seventy-five years later. In an earlier speech in the 1932 campaign, Roosevelt had laid out his fundamentally pragmatic approach to governing. "The country needs," he said, "and, unless I mistake its temper, the country demands bold, persistent experimentation. It is common sense to take a method and try it: If it fails, admit it frankly and try another. But above all, try something" (Roosevelt 1938, 646). This is not exactly a manifesto for what we have come to know as New Deal liberalism, 
but it is a clear statement of Roosevelt's governing philosophy and the approach that distinguished him from what had come before.

\section{LOOKING FORWARD: OBAMA AND THE FUTURE OF POLICY}

Which brings us back to Barack Obama once again. What does this broad historical survey tell us about prospects for Obama's foreign policy? Above all, what we learn is that the first defining fact of Barack Obama's presidency is that he is not George W. Bush. This may sound like a trivial fact, but it is a supremely important one. Obama comes to the White House following a president whose term in office was almost exclusively defined by foreign policy and whose approach to policy has been thoroughly discredited. Obama's overwhelming mandate is to not be Bush. This status, combined with the sweeping breadth and scope of Obama's victory -it the most decisive and lopsided presidential election in twenty years- gives Obama enormous license to create a new policy approach, and a new policy regime, on the ruins of the old. No president will be again be able to adopt the Reagan-Bush approach to foreign policy: unilateralism, bold (and often reckless) use of American military power, skepticism toward international law, and the presumption of complete presidential dominance in foreign policymaking. The question is, what will emerge in its place?

Obama comes into office resolutely opposed to all of these things. We can quickly and easily tick off some of the critical ways in which Obama seems intent on reversing or relaxing Bush's policies. It is in Iraq, the policy area in which Obama first sought to distinguish himself as a candidate for president, his policy direction has ironically not strayed terribly far from where the Bush administration ended up. Bush's reformed counterinsurgency strategy of 2007-8, known colloquially as the "surge," seems in fact to have produced greater stability in the country, to the point that before leaving office, Bush and Iraqi Prime Minister Nouri al-Maliki had signed a status of forces agreement calling for the eventual withdrawal of most American troops from the country. Obama has announced that American troops will be withdrawn somewhat faster than the schedule in the agreement, but he has acknowledged that the United States will likely leave a "transitional force" of $35-50,000$ troops in Iraq, possibly indefinitely. Obama has also announced an increase in American troop commitments to Afghanistan, signaling an important shift away from the Iraq-centered policy of Bush's "War on Terror" toward a more direct engagement with alQaeda. In the same region, Obama has signaled a move toward diplomatic engagement with Iran, a country that Bush held at arm's length as part of an "axis of evil" (a very Reagan-like phrase) (Bush 2004, 131). And by engaging Iran, Obama signals a potential shift in American relations with Israel, Iran's mortal enemy but a close friend of the United States. On the prosecution of the "war on terror," Obama has already reversed many of Bush's policies, including announcing the eventual closing of the detention camp at Guantánamo Bay in Cuba and he has signaled that his administration will be more openly respectful of international law regarding the detention and treatment of prisoners,. But it has been very cautious in deciding how it will deal with the detainees at Guantánamo and elsewhere. The president has been very careful to back away from the harsh unilateralism 
of the Bush administration's approach to foreign relations on a variety of issues, including nuclear proliferation, climate change, and the fight against terrorism. But he has been equally careful to preserve for the United States, and himself, the freedom to act when he deems it to be in the country's, and his, best interest. And he has exercised this freedom already in situations from piracy in the Indian Ocean to airstrikes against al-Qaeda and Taliban targets inside Pakistan.

But Obama is not without constraints in taking these steps. Although the president of the United States is less constrained in foreign policymaking than on the domestic side, he still needs cooperation from Congress to make policy. In some cases, the president has a lot of freedom in setting and reversing policy by executive action alone. In other cases, he does not. Take, for example, Obama's recent announcement about policy changes toward Cuba, particularly relaxing restrictions on travel and remittances between relatives. Many observers criticized this move as being very small, barely a change from the Bush-era policy. But most major Cuba policy is written into United States law; fully lifting the embargo or normalizing relations with Cuba would require changing the law, which would require an act of Congress. This would provoke a big political fight, and given the other priorities of the administration it seems unlikely that Obama will want to attempt this in the near future. As another example, one of Obama's most far-reaching foreign policy initiatives in my mind is the military budget that he and Secretary of Defense Robert Gates announced several weeks ago. This budget outlines a new, reformed approach to military funding and equipment, proposing substantially reduced spending on outdated and overly expensive weapons systems and emphasizing instead the imperatives of the kinds of wars the United States is actually fighting: manpower, intelligence, and deterrence. Fareed Zakaria (2009a) of Newsweek has called the Gates budget "nothing short of revolutionary". But this approach will not pass easily. Many forces have lined up against it: defense and national security contractors, the armed services themselves, and members of Congress, who want to protect jobs in their states and districts. To take one example, the F-22 fighter plane, a plane designed in the 1980s for dogfights with Soviet fighters, is now in production even though it is effectively obsolete as a militarily useful piece of equipment. Why? Well, for one thing, various parts of it are manufactured in forty-four states (out of fifty), giving almost every member of Congress some reason to protect it regardless of their views on foreign or defense policy or military procurement (Zakaria 2009b). This is just a small taste of the kind of political opposition that Obama can expect to many of his policy initiatives - in Congress, where Republicans retain the power to block or delay legislation, and in the array of interests who might have reason to oppose him. The Republicans in Congress have already shown that they are prepared to oppose the president's policy proposal unanimously when they think it serves their interest, so he will have to rely on carefully calibrated compromises to push his agenda. It is worth recalling that Reagan, and even Roosevelt, was in the same position and that many of their great policy accomplishments were also the result of compromises with opposition forces. At moments of political transformation such as the one we are in, these opposition forces are substantially weakened, to be sure. Just now, the Republicans have very little in the way of actual 
alternative ideas, in foreign policy or any other area, and are reduced to trying to put stumbling blocks in the administration's path. But the American governmental system of separated powers makes it unusually easy for a determined opposition to do this, and we should not forget that Obama will not make policy without the constraints imposed by this system.

What, in the end, can we make of this short foreign-policy record? Primarily, I think, that Obama is following the script of early regime-changing presidents. He is, above all, determined to distinguish his administration from his discredited predecessor, and in broad outlines he is beginning to accomplish this. But he is also determined to act pragmatically, meeting individual situations and addressing individual conflicts without the constraint of a particular ideological framework. Is there an Obama Doctrine emerging in these early days? If there is, I don't see it. What there is, as the New York Times has suggested, is an anti-Bush doctrine, a determination to pull back from fragile commitments of the Bush administration and to strike off in a new direction. This anti-Bush approach, I think, is entirely consistent with Obama's historical position as a potentially regime-changing president. But equally consistent with that position is his failure thus far to prescribe a new doctrine. That may come; Obama may very well, over the course of his presidency, establish a new and recognizable foreign policy regime. If he does, it will likely be built on the pillars he is now erecting: multilateralism, at least rhetorical respect for the rule of law in international affairs, and a military more closely calibrated to the post-cold war world. But if an Obama doctrine emerges, if Obama's presidency successfully establishes a new foreign-policy regime in American politics, it will come about not from the actions of the first hundred days, nor because the president is following a predetermined ideological script. It will happen, I think, in ways and under circumstances that we cannot yet imagine.

\section{REFERENCES}

Badger, Anthony J. 1989. The New Deal: The Depression Years, 1933-40. New York: Hill and Wang. Burner, David. 1979. Herbert Hoover: A Public Life. New York: Alfred A. Knopf.

Bush, George W. 2004. "Address Before a Joint Session of Congress on the State of the Union, January 29, 2002". Public Papers of the Presidents of the United States, George W. Bush, 2002. Washington: Government Printing Office.

Carter, Susan B. 2006. "Labor Force, Employment, and Unemployment: 1890-1990," Table Ba470-477. In Historical Statistics of the United States, Earliest Times to the Present: Millennial Edition, edited by Susan B. Carter, Scott Sigmund Gartner, Michael R. Haines, Alan L. Olmstead, Richard Sutch, and Gavin Wright. Cambridge: Cambridge University Press.

Dallek, Robert. 1979. Franklin D. Roosevelt and American Foreign Policy, 1932-1945. New York: Oxford University Press.

DeConde, Alexander. 1951. Herbert Hoover's Latin-American Policy. Stanford: Stanford University Press.

Dionne, E. J., Jr. 2009. “The Obama Doctrine". Washington Post, April 16.

Dobbs, Michael. 2007. "Obama Tells a Fib". Washington Post, November 28. http:/ / voices.washingtonpost. com/fact-checker/2007/11/obama_tells_a_whopper_1.html

Donald, David Herbert. 1995. Lincoln. New York: Simon and Schuster. 
Fraser, Steve, and Gary Gerstle, eds. 1989. The Rise and Fall of the New Deal Order, 1930-1980. Princeton: Princeton University Press.

Hawley, Ellis W. 1966. The New Deal and the Problem of Monopoly: A Study in Economic Ambivalence. Princeton: Princeton University Press.

Hofstadter, Richard. 1948. The American Political Tradition and the Men Who Made It. New York: Alfred A. Knopf. Hoff, Joan. 1994. Nixon Reconsidered. New York: Basic Books.

LaFeber, Walter. 1983. Inevitable Revolutions: The United States in Central America. New York: W. W. Norton. Leuchtenburg, William E. 1963. Franklin D. Roosevelt and the New Deal, 1932-1940. New York: Harper \& Row. Leuchtenburg, William E. 1983. In the Shadow of FDR: From Harry Truman to Ronald Reagan. Ithaca: Cornell University Press.

Mahbubani, Kishore. 2008. "If the World Could Vote". Newsweek International, January 14.

Obama, Barack. 2004. Dreams From My Father: A Story of Race and Inheritance. New York: Crown Publishers.

Reagan, Ronald. 1984. "Remarks at the Annual Convention of the National Association of Evangelicals in Orlando, Florida, March 8, 1983". Public Papers of the Presidents of the United States, Ronald Reagan, 1983. Washington: Government Printing Office.

Roosevelt, Franklin D. 1938. The Public Papers and Addresses of Franklin D. Roosevelt, Volume 1: The Genesis of the New Deal. New York: Random House.

Sanger, David E. 2009. "Hints of Obama's Strategy in a Telling 8 Days". New York Times, April 7.

Schulman, Bruce J. 2001. The Seventies: The Great Shift in American Culture, Society, and Politics. New York: Free Press.

Skowronek, Stephen. 1993. The Politics Presidents Make: Leadership from John Adams to George Bush. Cambridge: Harvard University Press.

Smith, Adam M. 2003. “Our Sitting President: Bush's Lack of Foreign Travel Undermines American Diplomacy". American Prospect, June 1.

Wallis, John Joseph. 2006. “Federal Government Debt by Type: 1790-1970," Table Ea650-661. In Historical Statistics of the United States, Earliest Times to the Present: Millennial Edition, edited by Susan B. Carter, Scott Sigmund Gartner, Michael R. Haines, Alan L. Olmstead, Richard Sutch, and Gavin Wright. Cambridge: Cambridge University Press.

Wicker, Tom. 1991. One of Us: Richard Nixon and the American Dream. New York: Random House.

Zakaria, Fareed. 2009a. Fareed Zakaria GPS, CNN,April 12. http:/ /transcripts.cnn.com/TRANSCRIPTS/0904/12/ fzgps.01.html

Zakaria, Fareed. 2009b. “Is Robert Gates a Genius?" Newsweek, April 20.

Robert C. Lieberman is Professor of Political Science and Public Affairs and Vice Dean for Academic Affairs of the School of International Affairs at Columbia University. He is the author of two books, Shifting the Color Line: Race and the American Welfare State (Harvard University Press, 2001) and Shaping Race Policy: The United States in Comparative Perspective (Princeton University Press, 2007), as well as numerous articles on American politics and public policy. (E-mail:rcl15@columbia.edu). 
